\title{
Coordination of public infrastructure solution for preventing of accidents
}

\author{
Václav Jetel ${ }^{1, *}$ \\ ${ }^{1}$ Czech Technical University in Prague, Faculty of Civil Engineering, Department of Urban Design, \\ Town and Regional Planning, Thákurova 7, 16629 Praha 6
}

\begin{abstract}
Coordination on public infrastructure is an integral part of any town and country planning process, which aims to provide unlimited uptime of all systems, providing basic needs in settlements that cannot cause outages, failures and accidents of the systems themselves, threaten public safety or cause defects or even destruction of the surrounding buildings. The paper describes the selected policy coordination on technical equipment area, which monitors the stability of the surrounding buildings, eliminating the potential defects, using scientific and educational knowledge in the field of municipal engineering. In the end, against the backdrop of actual accidents and failures of utilities, can be documented need for a comprehensive approach to the design of public infrastructure, already in the planning preparation in approving land-use plans, regulatory plans and decision-making in the planning stages.
\end{abstract}

\section{Introduction}

Coordination on public infrastructure is one of the most important activities of their operators, municipal engineers, architects, urban planners, economists, environmentalists, politicians and concerned government authorities. That this activity is properly implemented, it must be set within a framework of rules laws and their implementing regulations, standards, technical requirements and guidance, based on claims on public infrastructure. One of the missions of the Department of Urban Design, Town and Regional Planning, in Czech Technical University in Prague, then prepare professionals for the building industry, who will be able in a variety of jobs to seek optimal solution for the future construction of public infrastructure so as not to limit its operability, and while that may not cause outages, failures and crash the systems themselves, threaten public safety or cause defects or even destruction of the surrounding buildings. Already in a planning process, which this article focuses, can significantly affect the future behaviour of buildings and structures for eliminate any malfunctions. An important instrument for coordinating public infrastructure solutions have become the planning analytical materials, whose main theme is just preventing threats in the area, which could cause the collapse of individual buildings.

\footnotetext{
*Corresponding author: vaclav.jetel@,fsv.cvut.cz
} 


\section{Public infrastructure}

Infrastructure is the basic facilities, services, and installations needed for the functioning of a community or society, such as transportation and communications systems, water and power lines, and public institutions including schools, post offices, and prisons. The design and engineering of infrastructure was historically conceived in isolation, independent of the overall urban vision. Infrastructural system is often hidden from view, apparent, which breeds unhappy surprises and mounting frustration when the system fails. [1]

In the frame of legislation Planning and Building Code, public infrastructure are land, buildings and transportation infrastructure facilities, technical infrastructure, civic amenities and public spaces, and to set up and used in the public interest.

Table 1. Public infrastructure under the Building act.

\begin{tabular}{|c|l|}
\hline Transport infrastructure & $\begin{array}{l}\text { for example, the structures of roads, railways, waterways, } \\
\text { airports and the facilities related to them [2] }\end{array}$ \\
\hline Technical infrastructure & $\begin{array}{l}\text { the lines and the structures and to them operationally } \\
\text { related facilities of technical equipment, for example, } \\
\text { water mains, distribution reservoirs, waste water sewage, } \\
\text { waste water treatment plants, structures and facilities for } \\
\text { waste disposal, transformer stations, power distribution } \\
\text { lines, communication lines of public communication } \\
\text { network and electronic communication equipment, } \\
\text { product pipe lines [2] }\end{array}$ \\
\hline Public services & $\begin{array}{l}\text { the structures, facilities and lands serving, for example, for } \\
\text { training and education, social services and care of family, } \\
\text { health services, culture, public administration, protection } \\
\text { of inhabitants [2] }\end{array}$ \\
\hline Public space & $\begin{array}{l}\text { all squares, streets, marketplaces, sidewalks, public } \\
\text { greenery, parks and other areas accessible to everyone } \\
\text { without restriction, ie for general use, regardless of } \\
\text { ownership of the space [3] }\end{array}$ \\
\hline
\end{tabular}

\section{Coordination of technical equipment area}

Activities under the coordination of the technical facilities of the area can be defined as the ability to file joint solutions to problems, problems of various kinds of utilities, interrelated, which is necessary to deal preventively to avoid especially for our environment.

Coordination can be divided into several following topics:

- spatial,

- technical and economic,

- technology,

- technical and ecological,

- coordination on their mutual direct functional links or links to other elements,

- coordination ways of addressing modes and load, flow systems, reliability, security, technical documentation solutions and more.

In planning activities apply to individual coordination of spatial planning instruments, which are defined in the Building Act and which have different implications in the context of specific outputs. 
Each instrument has its own territorial scope, scale and detail solutions to problems ranging from the most general nationwide (Spatial development policy) to detail the placement of buildings (regulatory plan).

\section{Selected town and country planning instruments}

\subsection{Planning analytical materials}

The planning analytical materials contain the ascertainment and assessment of the state and development of the area, its values, limitation of the changes in the area due to protection of public priorities, arising from the regulations or stipulated under the special regulations or arising from the properties of the area, programmes for executing the changes in the area, ascertaining and assessing the area sustainable development, and determination of problems for solution in the planning documentation [2].

To coordinate the territories currently have a pivotal role, since they give into the hands of designers and procurers of the necessary elements that define when a thorough analysis of possible problems in the concept of public infrastructure and set tasks for future planning activities. For the purpose of eliminating threats are the most important of these data on the area: undermining areas, landslide areas, contaminated areas, areas with poor air condition, floodplains, emergency zones, security zones and noise zones. In this year, taking place for the third full update planning analytical materials to evaluate current trends of development of the territory and its society since 2008 .

\subsection{Planning study}

Planning study suggests, examines and considers possible solutions of selected problems, or arrangements or the development of certain functional systems within the area, for example, the public infrastructure, territorial system of ecological stability, which could significantly impact or condition the utilization and arrangement of the areas or of their selected parts [2]. Currently, the main topics are studies of landscape and studies of public space. Now a study of public spaces may significantly affect the future conduct of public infrastructure in settlements, solve their problems and eliminate the threat.

\subsection{Spatial development policy of the Czech Republic}

The spatial development policy (SDP), with respect to the possibilities of the area, coordinates creation and updating of the development principles, creation of concepts approved by ministries and other central administrative authorities, and programmes for the changes in the territory of the national wide importance, and determines the tasks ensuring this coordination [2]. SDP coordinates also intentions to make changes to the area for transport and technical infrastructure that impacts territories of several regions due to its significance, extension or foreseen usage. SDP delimit areas with development potential within inundation spaces and locate public infrastructure in there, fi nanced from public budgets, in exceptional and well reasoned cases only. Delimit and protect areas with development potential for relocation of structures from spaces with high flood damages risks. 


\subsection{Development principles}

Development principles within the supra local context of the region's territory specify and develop the objectives and tasks of the town and country planning in accordance with the spatial development policy, they determine the strategy for their fulfilling and they coordinate the planning activities of municipalities [2]. The importance of coordination of development principles for example in Prague completely suppressed and the Prague Institute of Planning and Development rather understands the importance of setting priorities for city development and definition of the construction of transport and technical infrastructure are important for the function of the city as a whole.

\subsection{Master plan}

The master plan determines the basic concept of the development of the municipality, protection of its values, its areal and spatial arrangement, arrangement of the landscape, and the concept of the public infrastructure; delimits the developed area, areas and corridors, especially the areas with development potential and the areas delimited for the alteration of the existing development, for redevelopment or repeated utilization of the depreciated area, for public works, for public benefit measures, and for the territorial reserves and determines the conditions for utilization of these areas and corridors [2]. Concept of public infrastructure is one of the most important concepts in the master plan, which already includes specific solutions to problems that can cause a real threat in the area. Measures to eliminate threats in the public interest and can restrict the right to property. An important part of the master plan is defined territorial measures in case of an emergency or natural disaster. Often, however, these measures zoning plan completed only formally.

\subsection{Regulatory plan}

The regulatory plan within the settled area determines the detailed conditions for the use of the grounds, for location and spatial arrangement of structures, for protection of values and character of the area, and for creation of a favourable environment. The regulatory plan always determines the conditions for delimitation and the use of the grounds, for location and spatial arrangement of the structures of the public infrastructure, and delimits the public works or the public benefit measures [2]. Thanks to detail with which the regulatory plans are working (at the level of planning permission), can specifically identify and locate such measures that eliminate potential threats in specific locations. Here we use the services of specific standards, which set rules for the placement of public infrastructure works, which are defined so as to eliminate potential threats.

\section{Conclusion}

Infrastructural systems operate in the background, people know that they exist, but would rather forget about that. We are reminded of their existence when health and safety are at risk [1].

At the time this article was being prepared (26. 7. 2016), took place in Prague, Vysocanska Street, to drop the road where inside this crater of about $8 \times 4 \mathrm{~m}$ rammed passenger car. The road, by the Prague Water and Sewerage, collapsed after torrential rain due to the crash sewer. Water hollowed out cavern under the roadway, which caused the collapse of several meters of brick sewer ovoid shape. Damage to property was estimated at tens of millions of crowns. Cavern managed to stabilize the backfill, compacted and conclude concrete slab, which then allows repair brick sewer. This event illustrates the 
power of water, which can cause destruction of buildings and equipment unless they include in the draft utilities eventual elimination of possible threats, in case of floods, accidents, poor sewerage system, including a proposal for its implementation.

Accidents utilities should be eliminated in its occurrence appropriate precautions to avoid loss of human lives, environmental damage and economic losses.

One of the 10 largest industrial disasters after the 2nd World War was for example the gas pipeline accident in Guadalajara, Mexico, which caused gas leaks into the sewer system and subsequent explosion, the result of which was destroyed entire neighbourhoods. It was thus a combined disaster two utilities, which had the character of the use of weapons of mass destruction.

Table 2. Top industrial disasters (1945-1990) [4].

\begin{tabular}{|c|c|c|c|}
\hline Year & Location & Type & Deaths \\
\hline 1984 & Bhopal, India & Toxic vapour / methyl isocyanate & $2750-3849$ \\
\hline 1982 & Salang Pass, Afganistan & Toxic vapour / carbon monoxide & $1500-2700$ \\
\hline 1956 & Cali, Colombia & Explosion / ammunitions & 1200 \\
\hline 1958 & Kyshtym, Russia & Radioactive leak & 1118 \\
\hline 1947 & Texas City, USA & Explosion / ammonium nitrate & 576 \\
\hline 1989 & Acha Ufa, Russia & Explosion / natural gas & $500-575$ \\
\hline 1984 & Cubatao, Brazil & Explosion / gasoline & 508 \\
\hline 1984 & St Juan Ixhautepec, Mexico & Explosion / natural gas & $478-503$ \\
\hline 1992 & Zonguldak, Turkey & Mine explosion / gas & 388 \\
\hline 1983 & Nile River, Egypt & Explosion / natural gas & 317 \\
\hline 1992 & Guadalajara, Mexico & Sewer explosion / gas & 210 \\
\hline 1986 & Chernobyl, Ukraine & Explosion / radioctivity & $31-300$ \\
\hline
\end{tabular}

On the basis of these disasters and the large number of accidents with impacts to the environment we must still ask whether our public infrastructure administrators are able to ensure future safe operation of infrastructure that cannot be repeated similar events and that have all the systems under control. For example, most accidents in public infrastructure are associated with energy production and distribution, which is a tax on economic growth [5].

\section{References}

1. Landscape infrastructure: case studies by SWA (Birkhäuser, Basel, 2011)

2. Act no. 183/2006 Coll., Building Act (2006)

3. Act no. 128/2001 Coll., Municipality Act (2011)

4. S.L. Cutter, Hazards Vulnerability and Environmental Justice (Routledge, 2012)

5. P. Šrytr, Výpadky inženýrských sití z hlediska udržitelného rozvoje (Czech Technical University in Prague, Prague, 2009) 